\title{
Morphometric patterns of two fouling Eudendrium spp. (Hydrozoa, Anthomedusae, Eudendriidae) from São Sebastião (SP, SE Brazil)
}

\author{
Otto M.P. Oliveira ${ }^{1}$, Antonio C. Marques ${ }^{1, *}$ and Alvaro E. Migotto ${ }^{2}$ \\ ${ }^{1}$ Departamento de Biologia, Faculdade de Filosofia, Ciências e Letras de Ribeirão Preto, Universidade de São \\ Paulo, Av. Bandeirantes 3900, 14040-901, Ribeirão Preto - SP, Brazil; ${ }^{2}$ Centro de Biologia Marinha, Universidade \\ de São Paulo, Caixa Postal 83, $11600-970$ - São Sebastião - SP
}

\begin{abstract}
Thirty colonies of Eudendrium carneum and 100 colonies of E. glomeratum, collected on recruitment panels in São Sebastião (SP, SE Brazil), were studied concerning morphometrical parameters and compared with morphometrical data available from other locations. The results show that E. carneum from Brazil has a relatively smaller morphometric variation than colonies of E. glomeratum for Brazil and other areas. Both morphological and speciation causes are suggested as possible explanations for the high variation of E. glomeratum.
\end{abstract}

Key Words: Hydrozoa, Eudendrium, morphometry, taxonomy, Brazil

\section{INTRODUCTION}

Hydrozoan species typically exhibit high phenotypic variation (Cornelius, 1991; Gili \& Hughes, 1995). Nevertheless, unlike in certain other better known taxa (e.g. arthropods and vertebrates), variations are little studied and inadequately characterized. Refined morphometric studies have proven useful in interpretations of both the ecology (cf. Boero et al., 1986; Gili \& Hughes, 1995) and taxonomy ( $c f$. Marques, 1995) of the group.

The anthomedusan hydrozoan family Eudendriidae includes species noted by their morphological variation. As a result, the taxonomy of the group is complicated (Millard, 1975; Marinopoulos, 1992) and many sibling species may exist. Morphometric studies of the different colony forms might prove useful in clarifying systematic problems in the family, as shown in Marques (1995) or other studies using limited morphometric information (cf. e.g. Millard, 1975; Watson, 1985, 1987; Calder, 1988). In the same way, the understanding of ecological aspects of some species, such as the seasonality, have been inferred from morphometrical patterns (e.g. Boero et al., 1986).
The aim of this study was to contribute to morphometric knowledge concerning eudendriids, allowing possible comparisons among different populations of Eudendrium glomeratum Picard, 1951, and E. carneum Clarke, 1882, two of the most common representatives of the group present in the Brazilian and Australian coasts, and in the Mediterranean Sea.

\section{MATERIAL AND METHODS}

We studied 100 colonies of Eudendrium glomeratum and 30 colonies of E. carneum from Cabelo Gordo de Dentro beach, CEBIMar, São Sebastião, state of São Paulo, SE Brazil (234' S, $\left.45^{\circ} 26^{\prime} \mathrm{W}\right)$. Specimens were collected manually on artificial substratum (recruitment panels) during July/1996. The colonies were studied under stereomicroscope, several parameters were measured (Fig. 1), the morphology was characterized and specimens were dried out in drying ovens chambers and weighed. Other characters were also considered, including the number of entire polyps and those in a resorptive process (i.e., polyps without tentacles presumably

\footnotetext{
Author for correspondence
} 
regressing into a resting stage or dying), besides number of gonophores and branches of first order.

The data were statistically analyzed applying average and standard deviation, and using regression curves between height and dry weight, and height and number of polyps for both species. The calculated equations were $\mathrm{y}=\mathrm{a} \mathrm{x}^{\mathrm{b}}$ (c.f. Boero et al., 1986).

\section{RESULTS}

Average and standard deviation values for Eudendrium glomeratum are shown in Table 1. Morphologically, $84 \%$ of the colonies were radial while the remaining were planar. The hydranth inactivity rate (proportion of hydranths without tentacles in the total number of hydranths of the colony) was $19.6 \%$. Concerning the sexual maturation, $31 \%$ of the colonies had gonophores (female), while the remaining (69\%) were sterile. The tendency curves for the relation "height $\mathrm{X}$ dry weight" (Fig. 2) and "height X number of polyps" (Fig. 3) exhibit reasonable correlation rates $(\mathrm{r}=$ 0.694 and 0.753 respectively).

The results for E. carneum are presented in Table 2. Concerning colony form, $93.3 \%$ of the colonies were radial and $6.7 \%$ planar. The hydranth inactivity rate was $6.0 \%$. Only two colonies $(6.7 \%$ of the total) bore gonophores (males). The tendency curve for the relation "height $\mathrm{X}$ dry weight" (Fig. 4) had a higher correlation rate than E. glomeratum $(\mathrm{r}=0.718)$, however the same rate for the curve "height X number of polyps" (Fig. $5)$, was smaller $(r=0.654)$.

\section{DISCUSSION}

Eudendrium carneum and E. glomeratum were relatively constant in colony form (in spite of medium values of standard deviation). The former can be considered a medium to large species, being one of the biggest hydroids in the region of São Sebastião. Eudendrium glomeratum from São Sebastião has a medium

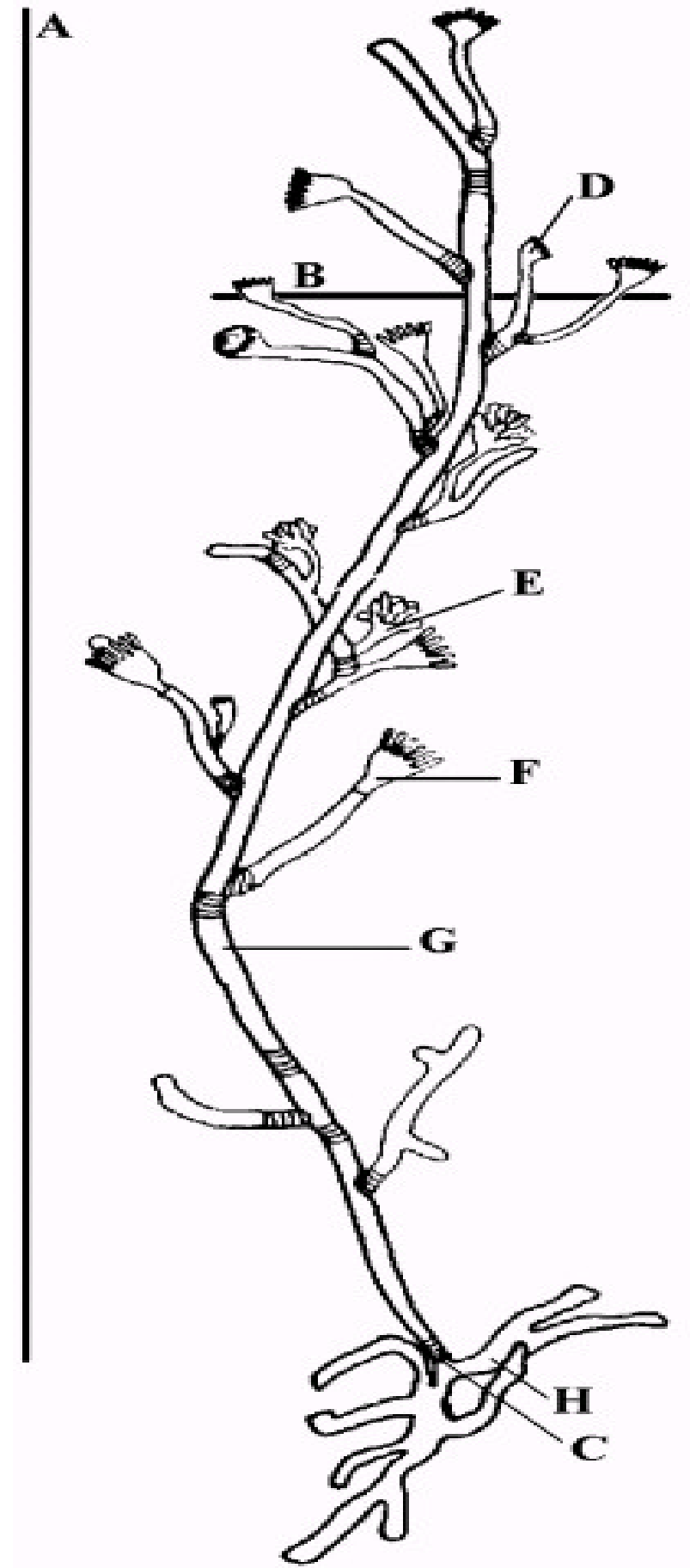

Figure 1 - Measurement parameters of the colonies. A, height; $\mathrm{B}$, maximum width; $\mathrm{C}$, base width; $\mathrm{D}$, polyp without tentacles; E, blastostyle; F, polyp with tentacles; G, hydrocaulus; H, hydrorhiza. (Modified from Marques, 1993).

colony size when compared to other species of the genus Eudendrium, which vary from small colonies of ca. $5 \mathrm{~mm}$ in height (e.g. E. fragile Motz-Kossowska, 1905; E. simplex Pieper, 1884; E. vervoorti Marques \& Migotto, 1998) to giant 
colonies of ca. $300 \mathrm{~mm}$ [e.g., E. rameum (Pallas, 1766)] ( $c f$. Marques, in press; Marques \& Migotto, 1998; Marques et. al., in press a, b).

Although E. glomeratum and E. carneum are considered easily recognizable through their general morphology ( $c f$. Watson, 1985; Marques et al., in press a, b), morphometrical comparisons between specimens from different locations, such as Brazil (Marques, in press), Australia (Watson, 1985) and the Mediterranean Sea (Boero et al., 1986; Bavestrello \& Piraino, 1991; Marques et. al., in press b) (tables 3-4) show that both species are remarkably variable.

The differences are more conspicuous in relation to E. glomeratum, especially comparing Brazilian and Mediterranean specimens studied by Boero $e t$ al. (1986). The colonies from Portofino Promontory (Genoa, Italy) are 10 times taller (maximum height) than the Brazilian colonies and have 17 times more polyps. However, the colonies from Australia are approximately of the same height of the Brazilian specimens ( $c f$. Watson, 1985, qualitative samples aiming taxonomy therein). Another significant difference is the strong fasciculation present in the Mediterranean colonies, whereas the Australian and Brazilian colonies are lightly fascicled or even unfascicled (the diameter at the base of the Brazilian colonies is about $192 \mu \mathrm{m})$. Although our data and Boero et al.'s (1986) data are comparable in relation to the absolute morphometry, the goals of the studies were different (morphometrical characterization herein vs. seasonal reproductive characterization therein), and we acknowledge that this different procedure in collecting data could obscure some morphometric parameters related to seasonality. There are no morphometrical studies on $E$. carneum in the literature. The available data on colony size are limited to species descriptions, such as the papers of Watson (1985), Calder (1988) and Bavestrello \& Piraino (1991). The maximum colony height varies from $18 \mathrm{~cm}$ (Australia) to $24 \mathrm{~cm}$ (Mediterranean). Although the herein studied specimens attain around the same height than those of Bermuda ( $c a .10 .5 \mathrm{~cm}$ or less), colonies of E. carneum from other locations in Brazil can be taller $(15 \mathrm{~cm}, c f$. Marques, in press).

The differences in colony shape and size pointed out above are rather significant, especially for $E$. glomeratum. Intraspecific morphological variations related to environmental factors have already been suggested for Eudendrium (Wedler, 1974, 1975; Mergner, 1977, 1987; Bandel \& Wedler, 1987): in some scenarios the colonies of shallow-water areas with stronger hydrodynamic conditions are smaller than those of deeper and calmer areas. Although we did not carry out experiments, we believe that the different hydrodynamical conditions in which the colonies from São Sebastião and Mediterranean Sea were subjected probably account for their distinct phenotypes. As the specimens from São Sebastião came from shallow waters $(\mathrm{ca} .2-3 \mathrm{~m})$ they were subjected to stronger water movements than the Mediterranean specimens studied by Boero et al. (1986) which were from deeper areas (ca. $30 \mathrm{~m}$ in depth), a more stable environment. According to Gili \& Hughes (1995), "hydroid size is commonly inversely correlated with water movement": within the same species, large specimens are usually found on calm and smaller specimens on agitated waters (see also Mergner, 1972, 1977, 1987; da Silveira \& Migotto, 1991).

Most of the colonies of E. carneum and $E$. glomeratum from Brazil were radial, although some were also planar. Distinct colony forms are also assumed to be related to water movement: colonies are radial under multidirectional flow or in places with weaker water movement, whereas colonies are planar in places with unidirectional water flow (Gili \& Hughes, 1995). Many cases of morphological variation due to hydrodynamical factors have been reported for tropical species. Morphological variation in Pennaria disticha Goldfuss, 1820 from the São Sebastião region was related to directions of water flow ( $c f$. da Silveira \& Migotto, 1991). 


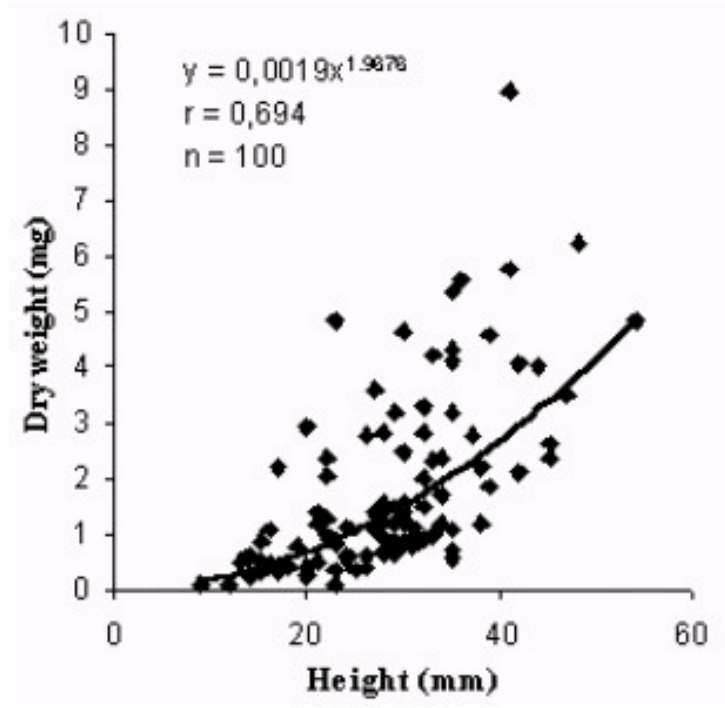

Figure 2 - Regression curve between height and dry weight of E. glomeratum.

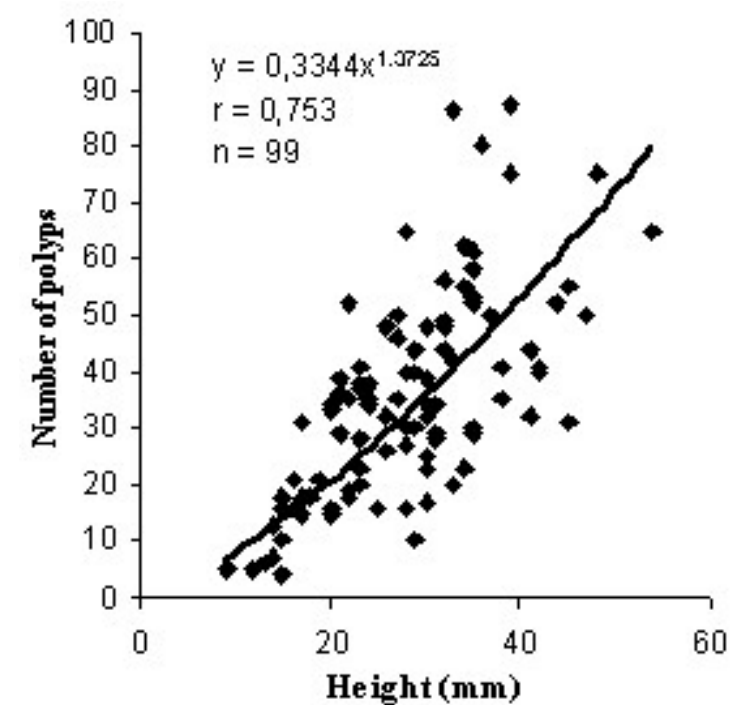

Figure 3 - Regression curve between height and number of polyps of E. glomeratum.

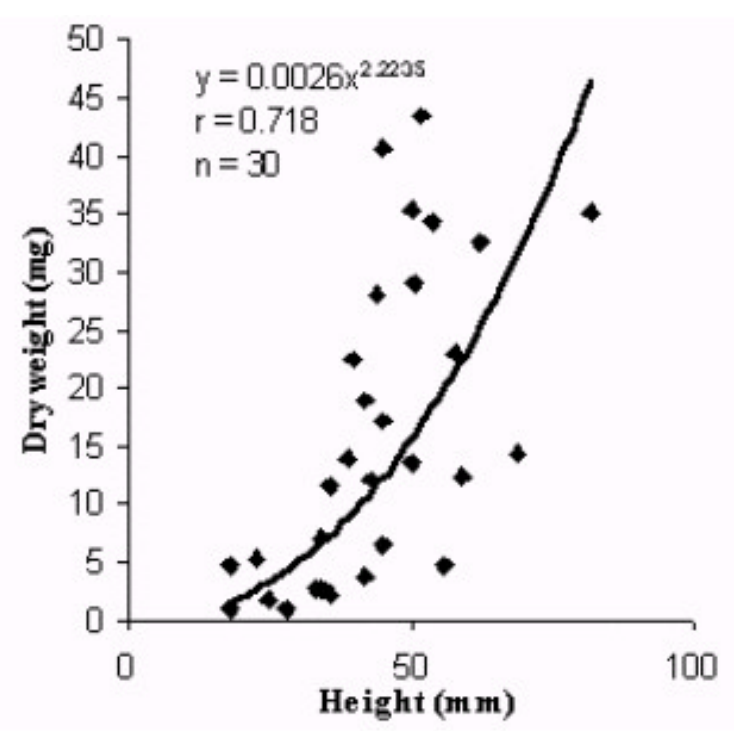

Figure 4 - Regression curve between height and dry weight of E. carneum.

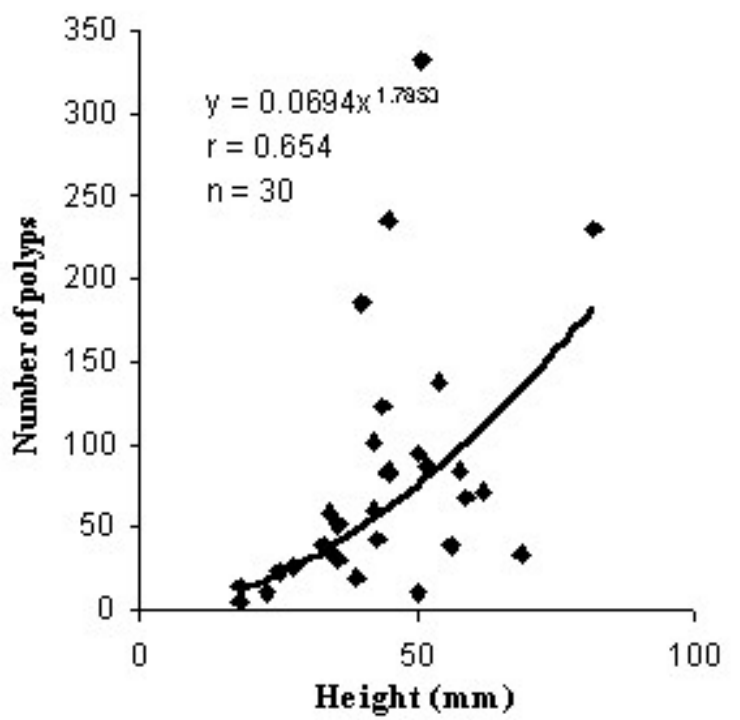

Figure 5 - Regression curve between height and number of polyps of E. carneum. 
Table 1 - Morphometrical results from the study of 100 colonies of E. glomeratum.

\begin{tabular}{lcccc}
\hline & Minimum & Maximum & Average & Std. Deviation \\
\hline Height $(\mathrm{mm})$ & 9 & 54 & 28.2 & 8.84 \\
Maximum width $(\mathrm{mm})$ & 3 & 22 & 8.7 & 4.06 \\
Base width $(\mu \mathrm{m})$ & 120 & 336 & 192.4 & 40.62 \\
Number of branches & 4 & 43 & 19.5 & 8.0 \\
Dry weight $(\mathrm{mg})$ & 0.09 & 8.98 & 1.95 & 1.81 \\
\hline
\end{tabular}

Table 2 - Morphometrical results from the study of 30 colonies of E. carneum.

\begin{tabular}{lcccc}
\hline & Minimum & Maximum & Average & Std. Deviation \\
\hline Height $(\mathrm{mm})$ & 18 & 82 & 43.7 & 14.57 \\
Maximum width $(\mathrm{mm})$ & 4 & 41 & 20.6 & 9.15 \\
Base width $(\mu \mathrm{m})$ & 168 & 2640 & 1130 & 687.6 \\
Number of branches & 4 & 25 & 15 & 5.2 \\
Dry weight $(\mathrm{mg})$ & 0.98 & 43.35 & 16.1 & 13.2 \\
\hline
\end{tabular}

Table 3 - Literature-based morphometrical data for E. glomeratum. (Mediterranean from Boero et al., 1986; Australia from Watson, 1985).

\begin{tabular}{lccc}
\hline & Brazil & Mediterranean & Australia \\
\hline Height $(\mathrm{cm})$ & $2.8 \pm 0.9$ & ca. 30.0 & 3.0 \\
Maximum width $(\mathrm{cm})$ & $0.8 \pm 0.4$ & $21.0^{*}$ & $1.3^{*}$ \\
Dry weight $(\mathrm{mg})$ & $1.95 \pm 1.81$ & ca. $508.6^{* *}$ & - \\
Basal fasciculation & light, when present & heavy & Light \\
\hline
\end{tabular}

* Measured from figures.

** Wet weight.

Table 4 - Literature-based morphometrical data for E. carneum. (Bermuda from Calder, 1988; Australian from Watson, 1985; Mediterranean from Bavestrello \& Piraino, 1991).

\begin{tabular}{lcccc}
\hline & Brazil & Bermuda & Mediterranean & Australia \\
\hline Height $(\mathrm{cm})$ & $4.4 \pm 1.4$ & ca. 10.5 & ca. 24 & ca. 18.0 \\
Maximum width $(\mathrm{cm})$ & $2.1 \pm 0.9$ & $5.3^{*}$ & ca. $15^{*}$ & - \\
Base width $(\mathrm{mm})$ & $1.13 \pm 0.69$ & - & $10^{*}$ & - \\
\hline
\end{tabular}

* Measured from figures. 
The unisexual condition observed (female for $E$. glomeratum and male for E. carneum) probably indicates that we were actually measuring distinct stems of a single colony produced by stolonial growth. However, a better understanding on this issue, as well on the inactivity rate of polyps (3 times higher in E. glomeratum), would only be clarified with seasonal studies of these species.

In both species the weight was proportional to the square of the height. An increase in height usually implies a proportional increase in the number of structures, such as branches and polyps, that consequently increases weight. But beyond a given height, as tall colonies demand strong (i.e., thick) stems to support themselves, this fact would work as a tendency to achieve basal fasciculation (only under the morphological perspectives, no evolutionary implications are assumed for now). Even so, fasciculation becomes inversely proportional to the number of branches at the base of the colony, simply because fascicled stems prevents the budding of first order lateral branches in the fascicled basal region. All these variations could explain why Mediterranean fascicled specimens of E. glomeratum have the weight varying with the cube of the height ( $c f$. Boero et al., 1986).

For Eudendrium carneum, polyp number varies with the square of colony height, while for $E$. glomeratum the number of polyps varies almost direct to the height (i.e., tending to a linear pattern). This contrasts with the data obtained by Boero et al. (1986) for Mediterranean colonies, which showed a variation between polyp number and height similar with the one we obtained for $E$. carneum. According to those authors, however, this was valid only for planar colonies; non-planar colonies grow in all directions and "for this reason the total weight of the colonies varies with the cube of the height". We saw no further theoretical differences between the radial and planar growth due to the habit, because this fact has apparently no implication on the distance between the origin of the first order branches (approximately the same in both cases) and because there is no sign of multiple budding of first order branches from the same origin of the stem of the specimens (i.e., opposite sensu Naumov, 1960, or multiple opposite arrangement). Hence, the major factor differentiating Mediterranean and Brazilian colonies in this case is the longer first order branches present in the Mediterranean colonies, consequently creating more space for budding polyps or second order branches independent of the height of the colony (because growth is not opposite, as explained above). Besides, longer branches are possible in calmer areas, otherwise the hydrodynamical effects would break them.

Although E. glomeratum is a species with a broad geographical distribution exhibiting different phenotypes according to environmental conditions, the hypothesis that it represents a complex of sibling species not evidenced through the characters adopted by the traditional taxonomy could not be discounted. Some morphological characters (e.g. the great fasciculation found in Mediterranean colonies, an absent or incipient condition in the Brazilian material) could be claimed as evidence in favor of this last hypothesis. Fasciculation of the Mediterranean colonies may be due to recruitment of planulae, produced synchronously, on the base of established colonies (Bavestrello \& Cerrano, 1992). This implies the occurrence of some kind of chemical recognition and histological compatibility (i.e., no rejection) between colony and planulae (cf. Schmid et al., 1992; although this recognition fails sometimes, see Marques, in press).

Tissue recognition and synchronic planulae release can be considered biological attributes of a given species (in this case of E. glomeratum), so it would be expected that the variations of the species shown above for morphometrical (and morphological parameters) should be more restricted (i.e., more stable morphology and less colony variation). However, the high variability in E. glomeratum suggests the possibility that we are dealing with allopatric lineages, difficult be characterized using traditional morphometrical analysis.

\section{ACKNOWLEDGMENTS}

The authors are grateful to the Centro de Biologia Marinha (CEBIMar-USP, São Sebastião, Brazil) and its staff for the logistical support, and to Eliana Fonseca for her help in gathering data. Our special thanks are to Prof. Wim Vervoort (Nationaal Natuurhistorisch Museum, Leiden, The Netherlands) and to Prof. H. Mergner and Dr. A. Svoboda (Ruhr-Universitat Bochum, Bochum, Germany) for providing the opportunity to study a wide range of different species from several geographical locations, to Dr. Dale R. Calder 
(Royal Ontario Museum, Toronto, Canada) for excellent suggestions concerning the manuscript. The study was supported by Fundação de Amparo à Pesquisa do Estado de São Paulo (FAPESP \# 93/3578-8; 95/3022-5; 96/10544-0; 97/04572-4; 98/11072-0).

\section{RESUMO}

Trinta colônias de Eudendrium carneum e 100 colônias de E. glomeratum foram coletadas em placas de recrutamento em São Sebastião (SP, SE Brasil), estudadas quanto aos parâmetros morfométricos e comparadas com dados de outras regiões. Os resultados mostraram que as colônias de E. carneum encontradas no Brasil possuem variações morfométricas relativamente menores que as colônias de E. glomeratum brasileiras e de outros lugares. Tanto causas morfológicas quanto especiação são sugeridas como possíveis explicações para a grande variação em $E$. glomeratum.

\section{REFERENCES}

Bandel, K.; Wedler, E. (1987), Hydroid, amphineuran and gastropod zonation in the littoral of the Caribbean Sea, Colombia. Senckenbergiana marit., 19(1-2), 1-129.

Bavestrello, G.; Cerrano, C. (1992), Aggregate colonies in Eudendrium glomeratum Picard 1952 (Cnidaria, Hydrozoa, Anthomedusae). Sci. Mar., 56(4), 333335.

Bavestrello, G.; Piraino, S. (1991), On two Eudendrium (Cnidaria, Hydrozoa) species from the Mediterranean Sea. Oebalia, n.s. 17, 197-207.

Boero, F.; Balduzzi, A.; Bavestrello, G.; Caffa, B.; Cattaneo Vietti, R. (1986), Population dynamics of Eudendrium glomeratum (Cnidaria: Anthomedusae) on the Portofino Promontory (Ligurian Sea). Mar. Biol., 92, 81-85.

Calder, D.R. (1988), Shallow-water hydroids of Bermuda: the Athecatae. Life Sci. Contr. R. Ontario Mus., 148, 1-107.

Cornelius, P.F.S. (1991), Relationships between the cnidarian classes and the loss of the medusa stage. Porcupine Newsletters, 5(1), 3-6.

Gili, J.; Hughes, R.G. (1995), The ecology of marine benthic hydroids. Oceanogr. mar. Biol., 33, 351-426.
Marinopoulos, J. (1992), Contribution à l'étude du genre Eudendrium (Hydrozoa: Hydroida) de la Méditerranée: taxinomie et phylogénie. Bull. Inst. océanogr. Monaco, $n^{o}$ spec. 9, 53-66.

Marques, A.C. (1993), Sistemática dos Eudendriidae L. Agassiz, 1862 (Cnidaria, Hydrozoa) do litoral paulista. M.Sc. Thesis, University of São Paulo, São Paulo, Brazil, 168 pp.

Marques, A.C. (1995), Eudendrium pocaruquarum n. sp. (Hydrozoa, Eudendriidae) from the southeastern coast of Brazil, with remarks on taxonomic approaches to the family Eudendriidae. Contr. Zool., 65(1), 35-40.

Marques, A.C. (in press), $\mathrm{O}$ gênero Eudendrium (Cnidaria, Hydrozoa, Anthomedusae) no Brasil. Pap. Av. Zool..

Marques, A.C.; Mergner, H.; Höinghaus, R.; Santos, C.M.S.; Vervoort, W. (in press a), Morphological study and taxonomical notes on some Eudendriidae (Cnidaria, Hydrozoa, Anthomedusae). Zool. Verh.

Marques, A.C.; Migotto, A.E. (1998), A new species of Eudendrium (Hydrozoa: Anthomedusae: Eudendriidae) from the Netherlands. Zool. Verh., 323, 149-154.

Marques, A.C.; Peña-Cantero, A.L.; Vervoort, W. (in press b), On the Mediterranean species of Eudendrium (Hydrozoa, Anthomedusae, Eudendriidae) with the description of a new species. J. Zool.

Mergner, H., (1972), The influences of several ecological factors on the hydroid growth of some Jamaican coral cays. In- Proceedings of the 1st. International Symposium of Coral Reefs, 1969, eds. C. Mukundan; C.S. Gopinadha Pillai. Marine Biological Association of India, Cochin, pp. 275-290.

Mergner, H. (1977), Hydroids as indicator species of ecological parameters in Caribbean and Red Sea coral reefs. In- Proceedings of the III. International Coral Reef Symposyum, eds. D. L. Taylor. Rosenstiel School of Marine and Admospheric Science, Miami, pp. 119-125.

Mergner, H. (1987), Hydroids as indicator species of environmental factors on coral reefs. In- Modern trends in the Systematics, Ecology and Evolution of Hydroids and Hydromedusae, eds. J. Bouillon; F. Boero; F. Cicogna; P.F.S. Cornelius. Clarendon Press, Oxford, pp. 185-195.

Millard, N.A.H. (1975), Monograph on the hydroida of Southern Africa. Ann. S. Afr. Mus, 68, 1-513.

Naumov, D.V. (1960), Gidroidi i gidromedusy morskikh, solonovatovodnykh i presnovodnykh basseinov SSSR. - Opredeleteli po faune SSSR, Izdavaemye Zoologicheskim Institutom Akademii Nauk SSSR 70, 1-626 (in Russian). English translation by Israel Program for scientific translations, cat. no. 5108, as "Hydroids and Hydromedusae of the USSR", 1-631 (1969). 
Schmid, V.; Schuchert, P.; Piraino, S.; Boero, F. (1992), The mesogloea (extracellular matrix) of hydrozoans can be species-specific for cell attachment and cell migration: a new tool for taxonomists? Sci. Mar., 56(2-3), 131-136.

Da Silveira, F.L.; Migotto, A.E. (1991), The variation of Halocordyle disticha (Cnidaria, Athecata) from the Brazilian coast: an environmental indicator species? Hydrobiologia. 216/217, 437-442.

Watson, J.E. (1985), The genus Eudendrium (Hydrozoa: Hydroida) from Australia. Proc. R. Soc. Vict., 97(4), 179-221.
Watson, J.E. (1987), Records of Eudendrium (Hydrozoa: Hydroida) from New Zealand. Proc. Linn. Soc. N.S.W., 109(4), 325-330.

Wedler, E. (1974), Zur Ökologie der Hydroidpolypen aus dem tropischen litoralgebiet der Umgebung von Santa Marta. Thesis of Bochum University, Germany. Wedler, E. (1975), Ökologie Untersuchungen an Hydroiden des Felslitorals von Santa Marta (Kolumbien). Helgolander wiss. Meeresunters. 27, 324-363.

Received: September 21, 1999; Revised: November 17, 1999; Accepted: March 13, 2000. 